\title{
Narrative Review about Importance of Nutrition on Survivors and in the Prevention of Cancer
}

\author{
Revisão narrativa sobre a importância da nutrição em sobreviventes e na prevenção do câncer \\ Giovanna Guimarães Lopes', Renan Gianotto Oliveira², Silvia Maria Fraga Piovacari', Maria do Carmo Azevedo \\ Leung $^{3}$, Diogo Oliveira Toledo ${ }^{4}$, Ana Paula Noronha Barrere ${ }^{1 *}$.
}

\begin{abstract}
Cancer is the second leading cause of death in Brazil. This study aimed to review the nutrition role in prevention and post-treatment of cancer as a health promoter. Regarding prevention, when analyzing lifestyle (obesity and physical activity), there was a positive correlation between body mass index and body fat with incidence in several types of cancer; physical activity shown an inverse correlation. Ethanol consumption, frying, red meat and processed meats eaten carefully or even avoided. Differently, the consumption of fruits and vegetables should be stimulated. Bioactive compounds are shown with well elucidated actions, and also as a healthy eating habit. In relation to survivors, the healthy lifestyle is capable of ensuring a better quality of life for this population, as well as preventing them from new diseases. This review highlights the importance of adequate lifestyle and eating habits, stimulates public health policy and more scientific research in this field.
\end{abstract}

Keywords: Primary prevention; Cancer survivors; Nutritional requirements; Healthy lifestyle.

\section{RESUMO}

O câncer é a segunda principal causa de morte no Brasil. Este estudo teve como objetivo revisar o papel da nutrição como promotor de saúde na prevenção e pós-tratamento do câncer. Em relação à prevenção, ao analisar o estilo de vida (obesidade e atividade física), houve correlação entre o índice de massa corporal e a gordura corporal com a incidência de vários tipos de câncer; atividade física apresentou correlação inversa. Consumo de etanol, fritura, carne vermelha e carnes processadas consumidas com cuidado ou até mesmo evitadas. Diferentemente, o consumo de frutas e vegetais deve ser estimulado. Compostos bioativos são apontados como esclarecidas boas ações e, também, como um hábito alimentar saudável. Em relação aos sobreviventes, o estilo de vida saudável é capaz de garantir melhor qualidade de vida para esta população, bem como previne-a de novas doenças. Esta revisão destaca a importância de um estilo de vida e hábitos alimentares adequados, estimula a política de saúde pública e mais pesquisas neste campo.

Descritores: Prevenção primária; Sobreviventes de câncer; Necessidades nutricionais; Estilo de vida saudável.

\footnotetext{
1. Hospital Israelita Albert Einstein, Clinical Nutrition Department - São Paulo - SP - Brazil

2. Clinical Hospital Campinas's University, Medical Clinical - Campinas - SP - Brazil

3. University São Camilo, Nutrition Department - São Paulo - SP - Brazil

4. Hospital Israelita Albert Einstein, Department of Nutritional Therapy - São Paulo - SP - Brazil

Financial support: none to declare.

Conflicts of interest: The authors declare no conflict of interest relevant to this manuscript.

Correspondence author: Ana Paula Noronha Barrere. Hospital Israelita Albert Einstein, Nutrition Department - São Paulo - SP - Brazil

Email: ana.barrere@einstein.br
}

Received on: April 2, 2019 | Accepted on: July 4, 2019

DOI: 10.5935/2526-8732.20190015 


\section{INTRODUCTION}

Cancer is the generic name for a group of more than 100 diseases that have in common the rapid and disorderly growth of cells that invade tissues and organs aggressively and uncontrollably that can give rise to malignant tumors. ${ }^{1,2}$ Currently, 75 million people live with cancer in the world, being the most common: lung, breast and colon cancer. By 2030, the expectation will be approximately 27 million new cases. ${ }^{2,3}$ In Brazil, the disease is already the second largest cause of death and the estimates are 600 thousand cases of the disease in the biennium 2016-2017. ${ }^{3}$

Cell growth control seems to depend on interrelated factors such as sustained angiogenesis, unlimited replicative potential, blockade of induction to apoptosis, self- sufficiency in growth signals and insensitivity to anti-growth signals. ${ }^{4}$ These factors occur somatically, in response to repeated health-damaging actions that may occur for decades, and promote erroneous cellular mutations leading to carcinogenesis. ${ }^{4,5}$

It would be considered external factors: social environment, occupational activity, smoking and lifestyle (sedentary lifestyle and eating). ${ }^{5}$ Eating habits can prevent three to four million new cases of cancer and prevent on average one-third of cancer deaths. ${ }^{3}$ It is known that dietary factors are extremely linked to oxidative damage in DNA. The ratio is so significant that $35 \%$ of cancers occur due to inadequate diets. ${ }^{3}$
Nutrition not only plays an important role in cancer prevention, but also is a great ally for the most important phase, the life quality post-cure. ${ }^{3}$ In addition, it is important to consider other factors such as families with germline mutations. ${ }^{4}$

Cancer survivors are individuals diagnosed with cancer who survived the treatment. It will be considered a survivor throughout their lives children and young people who are in total clinical remission for at least five years. The term "survivorship", in this case, refers to the life span of the cancer survivors. ${ }^{2,6,7}$

Global estimates of survivors are rising, following a worldwide trend. In 2002, global estimates of survival were less than 25 million, the outlook for 2025 is 50 million, and by 2050 it can be 70 million individuals. ${ }^{7}$

In Brazil, it is estimated that 8.2 million people live in this condition, about $4 \%$ of the total population. ${ }^{6}$ In the United States, the number of survivors increased from 3 million (1.5\% of population) in 1970 to more than 10 million (4\% of the population) in 2002. ${ }^{7}$ Estimates for 2050 is that it may double for elderly survivors (over 65 years). ${ }^{7}$

The objective of this study was to review the role of nutrition as a health promoter in the prevention and post-treatment of cancer, to verify the impact of lifestyle on the increased risk of posttreatment neoplasms, and to identify bioactive components capable of helping cancer prevention.

\section{METHODS}

This is a narrative bibliographical review that used guidelines and articles published since 2000, conducted in humans, in English and Portuguese. The databases used were EPIC (The European Prospective Investigation into Cancer and Nutrition), JAMA Network, American Cancer Society (ACS), Cancer Consensus and National and International Guides.

\section{RESULTS AND DISCUSSION}

We evaluated 39 references including guidelines and studies on nutrition in cancer, most of them were international studies published between 2007 and 2018. The literature mentions several risk factors that are related to cancer, such as smoking, infection, radiation, obesity, sedentary lifestyle, and others. The risk factors inherent or linked to nutrition were selected, such as obesity, physical activity, natural foods and their preparation. At first, the study will discuss the factors that encompass cancer prevention and then about the survivors.

\section{PREVENTION}

\section{A) Obesity}

Obesity is a public health problem in Brazil and around the world. Increased consumption of processed and ultra-processed foods has contributed to this epidemiological transition. ${ }^{8,9}$ It is a chronic disease with high inflammation of the tissues and it subsidizes several non-communicable chronic diseases such as diabetes mellitus, hypertension, coronary heart disease and cancer. 8,9

Epidemiological data from 2016 estimate that 1.97 billion adults and 338 million children and adolescents are overweight and obese. ${ }^{10}$ Studies such as that of Kushi et al. (2006) reinforce that environmental factors, eating habits, lifestyle and obesity are more linked than hereditary factors. ${ }^{11}$ In addition, systematic reviews indicate that overweight and obesity are clearly associated with increased risk for the cancers: breast in postmenopausal, colorectal, endometrial, kidney, stomach, pancreas and gallbladder. ${ }^{11}$

In a combined analysis of the International Beacon Consortium study, the risk of cancer was estimated an 
increase of 1.54 times for people with BMI 25-29.99 $\mathrm{kg} / \mathrm{m}^{2 ; 12}$ double for individuals with BMI between 30$34.9 \mathrm{~kg} / \mathrm{m}^{2}$ and five times for $\mathrm{BMI} \geq 40 \mathrm{~kg} / \mathrm{m}^{2}$, for oesophageal adenocarcinoma and oesophagogastric junction adenocarcinoma. ${ }^{11,12,13}$ Regarding to colon and rectum cancer, the interconnection is even more evident. Results of 60 studies and 86 control cases have demonstrated the positive relationship between increased body fat and cancer in this region. ${ }^{11,13}$

Neuhouser, Aragaki and Prentice (2015) ${ }^{14}$, a multicentric study on breast cancer and body composition, 67,142 American women, postmenopausal, between 50 and 79 years old were evaluated. In this article it has been suggested that obesity and overweight is a risk factor for breast cancer. ${ }^{14}$ Moreover, there was a strong association with Body Mass Index (BMI) above $35 \mathrm{~kg} /$ $\mathrm{m}^{2}$ (obesity II and III), with the risk of estrogen receptor-positive and progesterone receptor positive breast cancer, as well as, related to the increased risk for advanced stage disease. ${ }^{14}$ In a review of the American Institute for Cancer Research (2007), there is consensus from fifteen studies that BMI below $25 \mathrm{~kg} / \mathrm{m}^{2}$ is safe and healthy for disease control. ${ }^{7}$

\section{B) Physical Activity}

Sedentary lifestyle is a very important risk factor for several diseases, mainly because it contributes to increase body mass. ${ }^{8}$ The World Cancer Research Fund estimates that $20 \%$ of all cancers diagnosed in the United States are related to physical inactivity, excess body fat, excessive consumption of alcohol, and poor diet. ${ }^{10}$

The American Institute for Cancer Research (2018) recommends for adults, performing at least 150 minutes of moderate physical exercise (walking, swimming, biking, dancing and gardening) per week or a minimum of 75 minutes of very intense exercise per week (intense aerobic, cycling and running). ${ }^{10,15}$

Physical activity is also relevant in patients during treatment. ${ }^{15,16}$ The controlled studies cited by Campia and Barac (2016), with women with breast cancer and children with leukemia, ${ }^{18}$ suggested that after about 12 weeks of physical exercise, there was an improvement in respiratory pattern and endothelial function during chemotherapy. ${ }^{16,17,18}$

In a multicenter and multinational study by Veldhoven et al. (2011), 778 individuals with non-Hodgkin's lymphoma and 690 with non-Hodgkin's cell lymphoma were recruited to correlate immune regulation and the reduction of the development of this disease. ${ }^{19}$ It has been suggested that there is no relationship between physical activity and the prevention or attenuation of lymphomas or any variation of this type. ${ }^{19}$ Physical activity it seems to prevent various types of cancer, however, its role is better elucidated in breast, colon, prostate and endometrial cancer. ${ }^{15,19}$

\section{C) Nutrition}

Several foods may increase or decrease cancer risk by stimulating or inhibiting genetic mutations. ${ }^{7,10}$ Therefore, food choices are critical in disease prevention. , $10^{10}$ Therefore, the following will describe the main foods, highlighted by the literature, with potential activators or inhibitors of neoplasms.

\section{Red Meat}

The food habits of the majority of Brazilians are based on high consumption of red meat, mainly of bovine origin, due to the culture and great internal production in the southern region of the country. ${ }^{9}$

The American Cancer Society warns about the consumption of these foods. ${ }^{7,10}$ The recommendation should be limited to intake of lean, not charred, not processed, and until three or fewer servings per week.,10,20 In addition, it suggests the substitution of red meat by chicken, turkey or fish in order to prevent colorectal cancer and others that are strongly evidenced in the literature by intake of red meat., 70,20

The mechanism of induction to carcinogenesis in the ingestion of red meat is by stimulating the development of intestinal polyps, which can become malignant. ${ }^{20}$ In addition, red meats contain large amounts of heme iron, which in excess, causes intestinal cell toxicity. ${ }^{20}$ Evidence indicates that consuming 120 grams of red meat a day increases the risk of cancer by 1.2. ${ }^{21}$ About processed meat, the consumption of $30 \mathrm{~g}$ per day increased the risk to 1.09. ${ }^{21}$ The Zandonai, Sonobe and Sawada (2012) study shows that ingestion of red meat is associated with increased risk for colorectal cancer by 28 to $35 \% .{ }^{20}$ Processed meat is associated with increased risk by $20 \%$ to $49 \% .{ }^{21}$ There are indications that each daily portion of 50 grams of processed meat increases the risk for cancer to $18 \% .^{22}$

The population study of Bellavia, Stilling and Wolk (2016), published in the American Society for Nutrition, and conducted with 74,645 Swedish men and women, suggests that high red meat consumption increased risk by $21 \%$ for several causes, including $29 \%$ for cardiovascular disease, but no increasing risk factors for mortality related to cancer. ${ }^{23}$ In addition, no direct relationship was found between the consumption of vegetables with red meat, in relation to cardiovascular disease and cancer. ${ }^{23}$

Recommendations of the José Alencar Gomes da Silva Cancer National Institute (2017) ${ }^{22}$ comprise: ingestion less than $300 \mathrm{~g}$ of red meat per week and total exclusion of processed meat, such as turkey breast, salami, mortadella, ham, sausage, nuggets, and other ultraprocessed products. ${ }^{24}$ According to the American Institute for Cancer Research (2018) should limits the consumption of red meat to 3 servings per week (350-500g cooked, equivalent to 700$750 \mathrm{~g}$ raw meat) and also recommends the exclusion of processed meat. ${ }^{10}$ 


\section{Fruits and Vegetables}

Fruits and vegetables are food of great variety, easily accessible and inexpensive, which are available throughout the year. ${ }^{13}$ According to the American Cancer Society (2012), the recommended consumption of these foods is at least five servings per day, preferably of varied fruits and vegetables. ${ }^{15}$ When consumed, we benefit from a large pool of vitamins, minerals and antioxidants. ${ }^{15}$ Fruits and vegetables are sources of soluble and not soluble fiber that help to reduce possible inflammation caused by increased of cholesterol, avoid coronary heart disease, reduce obesity and diabetes mellitus. ${ }^{25}$

Aghajanpour et al. (2017) study highlights inulin fiber for having been shown to reduce the biological production of compounds related to colorectal cancer. ${ }^{25}$ The anti-carcinogenic cellular mechanisms developed by these fibers include: cell proliferation, decreased exposure to genotoxicity, and decreased release of interleukin-2. ${ }^{25}$ Several epidemiological studies have shown that the consumption of fruits and vegetables reduces the incidence of oral cancer, tongue, esophagus, stomach and colon. ${ }^{26}$ The recommendation is a daily intake of raw fruits and vegetables. ${ }^{26}$ It is estimated that daily and varied consumption can reduce the risk for cancer by 60 to $70 \%{ }^{27}$

\section{Soy}

In Brazil, bean consumption is very common, unlike Eastern countries. ${ }^{9}$ Soy is a nourishment of the same group of beans, extremely rich in nutrients, and offer in abundance the isoflavone, a phytochemical with beneficial health effects. ${ }^{9,15}$ The recommendation is to consume one portion of soybeans per day (approximately 25 grams), in its "in natura" or minimally processed form as the grain, flour and tofu meal, because in the processing there is loss of $70 \%$ of isoflavone. ${ }^{28}$ This substance is classified as phytoestrogen, with structure and function similar to the natural estrogen, blocking the action of the hormone, due to competition for the same active sites of estrogen receptor. ${ }^{28}$ In addition, isoflavone inhibits the action of $17 \beta$-hydroesteroid dehydrogenase, responsible for estrogen synthesis and induces serum steroid clearance. ${ }^{28}$

Messina et al. (2017) suggests that the relationship between soy consumption and breast cancer prevention is more effective when intake begins in childhood, since menarche in adolescence is associated with an increased risk of breast cancer. ${ }^{29}$ However, four studies have shown that soy intake in adolescence is still beneficial in reducing risk. ${ }^{29}$

In addition, the study by Baglia et al. (2016), conducted with 70,578 Chinese women aged $40-70$ years, demonstrates that high soy consumption during adolescence and adulthood is associated with a significant reduction in the risk of premenopausal breast cancer. ${ }^{30}$ Ultimately, if consumption in adolescence is low and adulthood is high, there is still a benefit in preventing postmenopausal breast cancer. ${ }^{30}$

\section{Alcohol ethanol}

Ethanol is the type of alcohol found in many alcoholic beverages, such as beers, wines, liqueurs, distillates and others. ${ }^{31,32}$ Evidence shows that ethanol is responsible for a strong link with the development of cancer, independently of the type of alcoholic beverage. ${ }^{31,32}$ Alcohol acts by being harmful in several regions of the body. In the oral cavity and throat acts as a strong irritant, damaging the cells that come in contact, which in cell repair can lead to changes in DNA and mutations, inducing cancer of the mouth and esophagus. ${ }^{31}$ In the intestine, colon and rectum colonizing bacteria can convert large amounts of alcohol into the cancerous chemical called acetaldehyde. ${ }^{31}$ In addition, ethanol byproducts harm the liver, leading to inflammation and healing, inducing repair to damage and thus increasing susceptibility to DNA errors. ${ }^{31,32}$

Therefore, recommendations of a wine glass ingestion daily, because of the resveratrol benefits, should be made with caution, or preferably replaced by whole grape juice. ${ }^{33}$ According to American Institute for Cancer Research (2018), there is no safe amount for alcohol intake, the recommendation is not to consume. ${ }^{10,30}$

The study of Jayasekara et al. (2018) proves that lifetime alcohol intake and rates of survival are consistent and alcohol improves about $50 \%$ risk of colorectal cancer. ${ }^{34}$ However, correlating evidence with differential risks by anatomic location or by molecular subtype is not well established. ${ }^{34}$

\section{Bioactive food compounds in cancer prevention}

Some "in natura" foods, in besides the function of nourishing, have particular components that are responsible for some metabolic and physiological actions. 9,33 This therapy through the bioactive compounds of foods is called chemoprevention. ${ }^{33}$

The antioxidant, anti-inflammatory, anti-hormonal and anti-angiogenic capacity of some foods can act in the inhibition, delay or reversion of the carcinogenic process, by stimulating tumor apoptosis. ${ }^{33}$ Among these compounds are lycopene, isoflavone, catechins, resveratrol, gingerol, curcumin, and others. Below we show the main compounds, already elucidated, and proven by the literature (Table I). ${ }^{33}$ It is worth mentioning that food becomes functional if consumed along with a complete and healthy diet and on a regular and continuous basis. ${ }^{33}$

\section{Source: SOUSA et al. (2017)}

In addition to the bioactive compounds mentioned above, there are other substances present in foods that play a similar mechanism of action, such as anthocyanins (present in grapes, cherries, strawberries, blackberries, apples, olives, figs, radishes, beans and eggplant); flavonoids and tannins (present in cocoa); and selenium (Brazil nut). ${ }^{33}$ 
Some vitamins also have this functional role, as is the case of beta-carotene that can be found in carrots, pumpkins, spinach, liver, mango, persimmon and beets, among others. ${ }^{30}$ All these components act in a beneficial way and behave as a prevention factor if consumed on a regular basis and in conjunction with a healthy lifestyle. ${ }^{33}$

\section{Food preparation}

Mode of preparation has a great influence on the nutritive value of the food. This phase requires a lot of attention, as doing so improperly may lead to nutritional losses in food and even to produce undesirable substances. ${ }^{35}$ Excessive fats in food preparation and frying are directly related to the formation of toxic products, which are potential carcinogens, such as acrolein and peroxides. In addition, by heating beyond the point of smoke or reusing oils, the chance of physical and chemical changes of this product increases, leading to the production of aldehydes, ketones, free radicals and trans fatty acids that are incorporated into foods and are extremely linked to cardiovascular disease, premature aging, arthritis, colon, breast and especially prostate cancer. 3,35

Smoked food contains a number of polycyclic substances such as benzopyrene fluoranthene, chrysene and

Table I. Bioactive compounds of food: mechanism of prevention of cancer

\begin{tabular}{|c|c|c|c|}
\hline Bioactive Compound & Food & Mechanism & Prevention of cancers \\
\hline Lycopene (Carotenoid) & $\begin{array}{l}\text { Ripe tomato "in } \\
\text { natura" and / or } \\
\text { cooked with oil. }\end{array}$ & $\begin{array}{l}\text { - Elimination of reactive oxygen species; } \\
\text { - detoxification system; } \\
\text { - Suppression of cell cycle progression; } \\
\text {-Modulation of the signal transduction } \\
\text { pathway. }\end{array}$ & Prostate and colon \\
\hline $\begin{array}{l}\text { Isoflavones } \\
\text { (phytoestrogen) }\end{array}$ & Soy & $\begin{array}{l}\text { - It acts on oxidative stress and } \\
\text { inflammatory response; } \\
\text { - It acts on the estrogen receptor; } \\
\text { - Production of cancer cells by behaving } \\
\text { in a similar way to the drug tamoxifen. }\end{array}$ & Breast cancer \\
\hline $\begin{array}{l}\text { Epigallocatechin-gal- } \\
\text { late (EGCC) } \\
\text { (Catechin) }\end{array}$ & $\begin{array}{l}\text { Green tea } \\
\text { (Camellia } \\
\text { sinensis) }\end{array}$ & $\begin{array}{l}\text { - Inhibits tumor invasion, angiogenesis } \\
\text { and metastasis; } \\
\text { - Prevents the wrong reproduction of } \\
\text { DNA; } \\
\text { - Induces the tumor cell apoptosis }\end{array}$ & Many types of cancer \\
\hline Curcumin & $\begin{array}{l}\text { Turmeric } \\
\text { (Curcuma longa) }\end{array}$ & $\begin{array}{l}\text { - COX-2 enzyme action; } \\
\text { - production of pro-inflammatory } \\
\text { cytokines (state of inflammation is } \\
\text { linked to the appearance of tumors); } \\
\text { - Potential chemopreventive (inhibits } \\
\text { carcinogenic process); }\end{array}$ & $\begin{array}{l}\text { Pancreas, gastric, } \\
\text { prostate, breast, oral, } \\
\text { hepatic, colorectal, } \\
\text { myeloid leukemia and } \\
\text { Hodgkin's lymphoma }\end{array}$ \\
\hline Glucosinolates & Brassicas & $\begin{array}{l}\text { - Anti-inflammatory; } \\
\text { - Suppression of IL-6 and TNF-a; } \\
\text { - Prevents mutation of cells. }\end{array}$ & $\begin{array}{l}\text { Colon, stomach, } \\
\text { intestine, colorectal, } \\
\text { kidneys, lungs and }\end{array}$ \\
\hline $\begin{array}{l}\text { Organosulfur } \\
\text { compounds }\end{array}$ & $\begin{array}{l}\text { Raw or cooked } \\
\text { garlic and } \\
\text { onion (keep } \\
\text { at maximum } \\
100^{\circ} \mathrm{C} \text { for } 20 \\
\text { minutes). }\end{array}$ & $\begin{array}{l}\text { - Antioxidant and anti-mutagenic action; } \\
\text { - Inhibition of oxidative damage; } \\
\text { - Induces cancer cell apoptosis and DNA } \\
\text { repair. }\end{array}$ & $\begin{array}{l}\text { Several types of } \\
\text { cancer, colorectal and } \\
\text { intestinal adenomas }\end{array}$ \\
\hline $\begin{array}{l}\text { Revesratrol } \\
\text { (Phytoalexin) }\end{array}$ & Grape and wine & $\begin{array}{l}\text { - Inhibits cell division and growth; } \\
\text { - It induces apoptosis of tumor cells; } \\
\text { - Reduces risk of metastasis; } \\
\text { - Cell cycle chemoprevention. }\end{array}$ & $\begin{array}{l}\text { Leukemia (B cells and } \\
\text { myeloid), colon and } \\
\text { skin }\end{array}$ \\
\hline $\begin{array}{l}\text { Lignins } \\
\text { (Phytoestrogens) }\end{array}$ & $\begin{array}{l}\text { Brown and } \\
\text { golden linseed }\end{array}$ & $\begin{array}{l}\text { - Antioxidant action (vitamin E + omega } \\
3 \text { + lignins); } \\
\text { - nti-mitotic action - inhibition of prolifera- } \\
\text { tion factor of tumor cells in a systemic way; } \\
\text { - Preservation of the basolateral } \\
\text { membrane - hinders the transport of } \\
\text { tumor cells to the lymphatic }\end{array}$ & Breast cancer \\
\hline Gingerol & Ginger & $\begin{array}{l}\text { - Ability to kill cancer cells that cause } \\
\text { mutations. }\end{array}$ & Several types of cancer \\
\hline
\end{tabular}


benzoaanthracene which are substances with carcinogenic power, especially for stomach cancer and large intestine. ${ }^{3,36}$ In addition, the study by Luzer (2017) complements the use of high temperatures to cook meat increases the concentrations of polycyclic aromatic hydrocarbons and other carcinogenic chemicals that may be related to breast cancer. ${ }^{36}$ The way of food conservation should also be taken into account, meat and fish that use salting as a conservation method, become potential carcinogens due to nitrosamines, especially nitrite and nitrate. ${ }^{37}$ These substances can also be found in large amounts in sausages and they are related to several types of tumors, especially gastric cancer. ${ }^{37}$ Dutra et al. (2007) shows a positive association between nasopharyngeal tumor and frequency of cured meats consumption, which contains high levels of nitrite. ${ }^{37}$

\section{Survivors}

Survivors, individuals who overcome the cancer, need a special clinical look, because many of which are still debilitated and have different nutritional demands. ${ }^{10,11}$ They should maintain healthy eating habits with desirable weight and encouraged to have a physically active lifestyle, as well as encouraging other actions to avoid induction of erroneous cell mutations. ${ }^{6,8,38}$ In addition, maintaining a healthy lifestyle after treatment is directly linked to decrease in cancer recurrence, risk of presenting a second type of cancer and decrease of developing non-communicable chronic diseases. ${ }^{6,38,39}$

Arends et al. (2017) recommends, as a strong level of recommendation, that cancer survivors should maintain a BMI between 18.5 and $25 \mathrm{~kg} / \mathrm{m}^{2}$ and have a healthy lifestyle, including physical activity, vegetables-rich diet, fruits and whole grains, and avoid saturated fat, red meat and alcohol. ${ }^{39}$ These changes of habit would also lead to benefits for individuals with chronic diseases such as diabetes, osteoporosis and coronary heart disease, which cancer survivors are more likely to have than healthy individuals. ${ }^{39}$ The dietary recommendations for these individuals follow the same line of prevention; however, they sometimes require adaptation because they present transient or permanent sequelae due to the treatment performed. ${ }^{6}$ Depending on the site of the treated tumor, these sequelae may cause changes in taste, disorders in intestinal absorption, and inappetence. ${ }^{6}$

Shu et al. (2009) tested the administration of 11 grams of daily soy protein, and it was suggested an inverse association between soy consumption compared to recurrence and mortality by breast cancer. ${ }^{28}$

However, Arends et al. (2017) study addressed a range of studies concluded that vegetable and veggies based diet has no significant impact on reducing the risk of cancer recurrence. This same study suggests the relationship between elevated serum levels of carotenoids from food and decreased relapse of breast cancer. ${ }^{39}$

The study performed by Sierpina et al. (2015) brings the results of large observational studies, and points out that typical foods of the Western diet (red meat, fat, refined grains, excess sugar) are related to double the mortality and triple the cancer recurrence. ${ }^{26}$ Luzer (2017) evidenced high consumption of grilled or smoked meat to increased mortality due to breast cancer. ${ }^{36}$ Arends et al. (2017) complements that high consumption of pork, beef, mutton is related to colorectal cancer, breast and high mortality rate. ${ }^{39}$

\section{CONCLUSION}

The importance of nutritional counseling to these survivors and the role of food, together with other healthy habits, in the prevention and posttreatment of oncology is undeniable. Nutrition, within the recommended context, may contribute to the inhibition of the carcinogenesis process. Foods contain compounds that, if consumed on a regular basis, can contribute to the prevention of diseases, among them cancer. The national and international scientific evidence is unanimous in affirming that lifestyle is one of the main factors of this disease.

\section{AUTHOR'S CONTRIBUTION}

Giovanna Guimarães Lopes: Collection and assembly of data, Data analysis and interpretation, Manuscript writing, Provision of study materials or patient.

Renan Gianotto Oliveira: Conception and design, Final approval of manuscript.

Silvia Maria Fraga Piovacari: Final approval of manuscript.
Maria do Carmo Azevedo Leung: Conception and design.

Diogo Oliveira Toledo: Collection and assembly of data, Final approval of manuscript.

Ana Paula Noronha Barrere: Conception and design, Final approval of manuscript, Provision of study materials or patient. 


\section{REFERENCES}

1. Ministério da Saúde (BR). Instituto Nacional de Câncer (INCA). A fisiopatologia do câncer [Internet]. Brasília: INCA; 2008; [cited 2017 ago 11]. Available from: http://www.inca.gov.br/ enfermagem/docs/cap2.pdf

2. Ministério da Saúde (BR). Instituto Nacional de Câncer José Alencar Gomes da Silva (INCA). Consenso Nacional de Nutrição Oncológica. 2a ed. Rio de Janeiro (RJ): INCA; 2016.

3. Dan LW, Pires FR, Silva ML, Kikuchi ST. Sociedade Beneficente Israelita Brasileira Albert Einstein. Guia Nutricional em Oncologia. São Paulo: Atheneu; 2017. p.29-40.

4. Hanahan D, Weinberg RA. Hallmarks of cancer: the next generation. Cell. 2011 Mar;144(5):646-74.

5. Ministério da Saúde (BR). Instituto Nacional de Câncer José Alencar Gomes da Silva (INCA). Consenso Nacional de Nutrição Oncológica. 2a ed. Rio de Janeiro (RJ): INCA; 2015.

6. Barrere APN, Noguchi DT, Gonçalves SEAB. Importância da alimentação nos sobreviventes de câncer (survivors). In: Barrére APN, Pereira A, Hamerschlak N, Piovacari SMF, organizadores. Guia Nutricional em Oncologia. 1a ed. Rio de Janeiro: Atheneu; 2017. p.203-210.

7. World Cancer Research Fund (WCRF). American Institute for Cancer Research (AICR). Food, Nutrition, Physical Activity, and the Prevention of Cancer: a Global Perspective. Washington, D.C.: AICR; 2007.

8. Associação Brasileira para o Estudo da Obesidade e da Síndrome Metabólica (ABESO). Diretrizes brasileiras de obesidade - 2016. 4a ed. São Paulo (SP): ABESO; 2016.

9. Ministério da Saúde (BR). Secretaria de Atenção à Saúde. Departamento de Atenção Básica. Guia alimentar para a população brasileira. 2a ed. Brasília (DF): Ministério da Saúde; 2014.

10. World Cancer Research Fund (WCRF). American Institute for Cancer Research (AICR). Continuous Update Project Expert Report - 2018. Recommendations and public health and policy implications. Washington, D.C.: AICR; 2018.

11. Kushi LH, ByersT, DoyleC, Bandera EV, McCullough M, McTiernan A, et al. American Cancer Society Guidelines on nutrition and physical activity for cancer prevention: reducing the risk of cancer with healthy food choices and physical activity. CA Cancer J Clin. 2012;62(1):30-67.

12. Hoyo C, Cook MB, Kamangar F, Freedman ND, Whiteman DC, Bernstein L, et al. Body mass index in relation to oesophageal and oesophagogastric junction adenocarcinomas: a pooled analysis from the International BEACON Consortium. Int J Epidemiol. 2012 dec;41(6):1706-18.
13. Pereira A, Mutti, HB, Zanella MT. In: Barrére APN, Pereira A, Hamerschlak N, Piovacari SMF. Guia Nutricional em Oncologia. São Paulo: Atheneu; 2017. p.66-71.

14. Neuhouser ML, Aragaki AK, Prentice RL. Overweight, obesity, and postmenopausal invasive breast cancer risk: a secondary analysis of the women's health initiative randomized clinical trials. JAMA Oncol. 2015 Aug;1(5):611-21.

15. Kushi HL, Doyle C, McCullough M, Rock CL, Demark-Wahnefried $W$, et al. American Cancer Society guidelines on nutrition and physical activity for cancer prevention. CA: A Cancer J Clin. 2012 Jan;62(1):1-10. IGUAL A REFERÊNCIA 11

16. Ferraz PLC, Fachina RJFG, Ferraz, RB. In: Barrére APN, Pereira A, Hamerschlak N, Piovacari SMF. Guia Nutricional em Oncologia. São Paulo: Atheneu; 2017. p.196-201.

17. Campia U, Barac A. Exercise and aerobic fitness to reduce cancer-related cardiovascular toxicity. Curr Treat Options Cardiovasc Med. 2016 Jul;18(7):44.

18. Järvelä LS, Niinikoski $H$, Heinonen OJ, et al. Endothelial function in long-term survivors of childhood acute lymphoblastic leukemia: effects of a home-based exercise program. Pediatr Blood Cancer. 2013 Sep;60(9):1546-51.

19. van Veldhoven $C M$, Khan $A E$, Teucher $B$, Rohrmann S, Raaschou-Nielsen O, Tjønneland A, et al. Physical activity and lymphoid neoplasms in the European prospective investigation into cancer and nutrition (EPIC). Eur J Cancer. 2011 Mar;47(5):748-60.

20. Zandonai AP, Sonobe HM, Sawada NO. Os fatores de riscos alimentares para câncer colorretal relacionado ao consumo de carnes. Rev Esc Enferm USP. 2012 Feb;46(1):234-9.

21. Larsson SC, WolkA. Meat consumption and risk of colorectal cancer: A meta-analysis of prospective studies. Int J Cancer. 2006 Dec;119(11):2657-64.

22. Ministério da Saúde (BR). Instituto Nacional de Câncer José Alencar Gomes da Silva (INCA). Carnes Vermelhas. Ministério da Saúde; 2017.

23. Bellavia A, Stilling F, Wolk A. High red meat intake and all-cause cardiovascular and câncer mortality: is the risk modified by fruit and vegetable intake?. Am J Clin Nutr. 2016 Oct;104(4):1137-1143.

24. Ministério da Saúde (BR). Instituto Nacional de Câncer José Alencar Gomes da Silva (INCA). OMS classifica carnes processadas como cancerígenas. Ministério da Saúde; 2015.

25. Aghajanpour M, Nazer MR, Obeidavi Z, Akbari $M$, Ezati $P$, Kor NM. Functional foods and their role in cancer prevention and health promotion: a comprehensive review. Am J Cancer Res. 2017 Apr;7(4):740-769. 
26. Sierpina V, Levine L, McKee J, Campbell C, Lian S, Frenkel M. Nutrition, metabolism, and integrative approaches in cancer survivors. Semin Oncol Nurs. 2015 Feb;31(1):42-52.

27. Carvalho PGB, Machado CMM, Moretti CL, Fonseca, ME. Hortaliças como alimentos funcionais. Hortic Bras [Internet]. 2006 Dec; [cited ANO mês dia]; 24(4):397-404. Available from: http://www.scielo.br/scielo.php?pid=S010205362006000400001 \&script = sci_ abstract\&tlng=pt

28. Shu XO, Zheng Y, Cai H, Gu K, Chen Z, Zheng W, Lu W. Soy food and breast cancer survival. JAMA. 2009 Dec;302(22):2437-43.

29. Messina M, Rogero MM, Fisberg M, Waitzberg D. Health impact of childhood and adolescent soy consumption. Nutr Rev. 2017 Jul;75(7):500-515.

30. Baglia ML, Zheng W, Li H, Yang G, Gao J, Gao YT, et al. The association of soy food consumption with the risk of subtype of breast cancers defined by hormone receptor and HER2 status. Int J Cancer. 2016 Aug;139(4):742-8.

31. American Cancer Society. Alcohol Use and Cancer [Internet]. USA: ACS; 2017; [cited 2019 Jun 20]. Available from: https://www.cancer. org/cancer/cancer-causes/diet-physical-activity/ alcohol-use-and-cancer.html

32. Praud D, Rota M, Rehm J, Shield K, Zatonski W, Hashibe $\mathrm{M}$, et al. Cancer incidence and mortality attributable to alcohol consumption. Int J Cancer. 2016 Mar;138(6):1380-7.
33. Sousa FC, Izeppe MJM. In: Barrére APN, Pereira A, Hamerschlak N, Piovacari SMF. Guia Nutricional em Oncologia. São Paulo: Atheneu; 2017;(1):184-194.

34. Jayasekara H, English DR, Haydon A, Hodge AM, Lynch BM, Rosty C, et al. Associations of alcohol intake, smoking, physical activity and obesity with survival following colorectal cancer diagnosis by stage, anatomic site and tumor molecular subtype. Int J Cancer. 2018 Jan;142(2):238-250.

35. Freire PCM, Mancini-Filho J, Ferreira TAPC. Principais alterações físico-químicas em óleos e gorduras submetidos ao processo de fritura por imersão: regulamentação e efeitos na saúde. Rev Nutr [Internet]. 2013 Jun; [cited ANO mês dia]; 26(3):353-358. Available from: http://www.scielo. br/scielo.php?script=sci_arttext\&pid=S141552732013000300010\&lng=en\&nrm=iso\&tlng=pt

36. Luzer D. Higher consumption of grilled, barbecued, and smoked meat linked to increased mortality risk among breast cancer survivors. J Natl Cancer Inst. 2017 Jan;109(6):djw333.

37. Dutra BC, Rath S, Reyes FGR. Nitrosaminas voláteis em alimentos. Alim Nutr. 2007 jan/ mar;18(1):111-120.

38. Rock LC, Doyle C, Demark-Wahnefried W, et al. Nutrition and physical activity guidelines for cancer survivors. CA Cancer J Clin. 2012 Jul/ Aug;62(4):243-74.

39. Arends J, Bachmann P, Baracos V, et al. ESPEN guidelines on nutrition in cancer patients. Clin Nutr. 2017 Feb;36(1):11-48. 